\title{
The Role of Serum Trace Elements and Oxidative Stress in Egyptian Breast Cancer Patients
}

\author{
Mona Mohamed K. El-Deeb1, Heba G. El-Sheredy2², Ayman Farouk Mohammed ${ }^{3}$ \\ ${ }^{1}$ Department of Chemical Pathology, Medical Research Institute, Alexandria University, Alexandria, Egypt \\ ${ }^{2}$ Department of Cancer Management and Research, Medical Research Institute, Alexandria University, \\ Alexandria, Egypt \\ ${ }^{3}$ Department of Surgery, Medical Research Institute, Alexandria University, Alexandria, Egypt \\ Email: mona_moh_eldeeb@yahoo.com, “Heba.gaber99@yahoo.com,Draly71@gmail.com
}

Received 5 January 2016; accepted 25 January 2016; published 28 January 2016

Copyright (C) 2016 by authors and Scientific Research Publishing Inc.

This work is licensed under the Creative Commons Attribution International License (CC BY).

http://creativecommons.org/licenses/by/4.0/

(c) (i) Open Access

\section{Abstract}

Background: Oxidative stress is considered to be involved in the pathophysiology of all cancers. Studies indicated that the levels of oxidative stress markers increased in breast cancer. Trace metals are essential to normal human homeostasis. When present in an abnormal expression, they contribute in many pathological processes. Some trace metals are claimed to be carcinogenic and capable of inducing a toxic effect through the formation of free radicles and acting as cofactors in the oxidative damage of biological macromolecules and DNA. Objective: Our aim was to investigate the serum levels of some trace elements (Copper, Zinc and Cadmium), the total oxidative and antioxidative capacity (TOC and TAC) in patients with breast cancer in comparison to patients with benign breast tumours. Patients and Methods: The present study included 65 females. The participates were divided into 2 main groups: control group which consisted of 20 apparently healthy female; the patient groups which divided into 3 groups: group B included 15 patients with benign breast tumours, group $\mathbf{N}$ consisted of 15 newly diagnosed breast cancer patients and group $M$ included 15 patients with metastatic breast cancer. Results: The mean serum levels of Copper, Zinc, and Cadmium were significantly higher in the three patients groups (B, $N$ and $M$ ) than the control group. Similarly, serum uric acid (UA) and (TAC) levels showed significant higher level in both breast cancer groups as compared to the benign group. However TOC levels showed only significantly higher level in metastatic group. Conclusions: The present study suggested elevated TAC, UA and TOC in breast cancer patients. The increased levels of trace elements could lead to formation of free radicals or other reactive oxygen species. The serum profile of these trace metals may be helpful in predicting prognosis of breast cancer.

\footnotetext{
${ }^{*}$ Corresponding author.
}

How to cite this paper: El-Deeb, M.M.K., El-Sheredy, H.G. and Mohammed, A.F. (2016) The Role of Serum Trace Elements and Oxidative Stress in Egyptian Breast Cancer Patients. Advances in Breast Cancer Research, 5, 37-47. 


\section{Keywords}

\section{Trace Elements, Oxidative Capacity, Breast Cancer, Antioxidants}

\section{Introduction}

Breast cancer is the most frequent malignant tumor in women worldwide. The incidence and mortality rates among women vary among countries, but are steadily increasing worldwide. Moreover, about half the breast cancer cases and $60 \%$ of the deaths have been reported to occur in the developing countries [1]. In Egypt, breast cancer is the most common cancer among women, representing 33.5\% of newly diagnosed cancer cases [2].

Much knowledge has been accumulated on the etiology and pathogenesis of breast cancer implicating genetic, hormonal and environmental factors [3]. Free radicals and other reactive oxygen species (ROS) are continuously produced inside the body from oxygen as a result of aerobic metabolism. Under healthy conditions at cellular level, a balance exists between the oxygen free radicals generation and the antioxidant defense mechanisms [4]. These free radicals can evoke extensive tissue damage, through reaction with macromolecules, such as membrane lipids, proteins, and nucleic acids [5]. The levels of free radical molecules are controlled by various cellular defense mechanisms (antioxidant mechanisms) consisting of enzymatic (glutathione peroxidase, superoxide dismutase) and non-enzymatic components (vitamin E, vitamin C, glutathione, uric acid) [6].

Oxidative stress is a phenomenon which indicates that antioxidant mechanisms are over whelmed by excessive reactive oxygen and nitrogen species generation. This phenomenon causes oxidative damage to biomolecules resulting in lipid peroxidation, mutagenesis and carcinogenesis [7]. Oxidative stress is considered to be involved in the pathophysiology of all cancers. Studies indicated that the levels of oxidative stress markers increased in breast cancer patients. This possibly may due to the disease process itself and tissue injury [8] [9].

Many antioxidative defenses, including vitamin $\mathrm{E}$ and ascorbic acid that prevent oxidative damage, are found in the various tissues. Uric acid, which acts as a powerful antioxidant in plasma, efficiently inhibits various kinds of oxidative damage to membranes [10]. Uric acid represents from $33 \%$ to $45 \%$ of the plasma antioxidant pool [10] [11].

Trace elements are found naturally in the environment. Human exposure to trace elements occurs through variety of sources, including air, drinking water and food. However, the degree of exposure to them is potentially modifiable [12]. Trace metals in right proportion and concentration, are essential to normal human homeostasis. The analysis of trace elements in human tissues has gained great interest due to the role that these elements play in normal biochemical and physiological processes. However, when in abnormal expression, they seem to contribute in several pathological processes [13].

In recent years, the association between trace elements and cancer has been studied, where some trace metals are claimed to be carcinogenic and capable of inducing a toxic effect through the formation of free radicles and acting as cofactors in the oxidative damage of biological macromolecules and DNA [14]. However, their exact role in carcinogenesis is still unclear. Moreover, data of the association of serum levels of trace element with cancer breast and their relation with oxidative stress and different tumour markers are still deficient [13].

Even though the increase in oxidative DNA lesions has been frequently attributed to metal exposures, it is important to note that the exact mechanism leading to tumor formation after such exposures is still not well understood. Several studies have shown that concentrations of trace elements are altered in neoplastic breast tissues. However, the microenvironment and metabolic changes caused by tumors are complex and still not completely understood [15].

The aim of the present study was to investigate the serum levels of some trace elements (Copper (Cu), Zinc (Zn) and Cadmium (Cd)), the total oxidative and anti-oxidative capacity (TOC and TAC) in newly diagnosed and metastatic cancer breast patients in comparison to their levels in patients with benign breast tumours in order to add more knowledge to their rule in these patients groups.

\section{Patients and Methods}

The present study included 65 females were enrolled and divided into two main groups; control group which consisted of 20 apparently healthy female volunteers of comparable age and socio-economic status to the patient 
groups; their mean age was $47.20 \pm 10.29$ years.

The patient groups which included patients with breast tumours and divided into 3 groups: group B that included 15 patients with benign non-proliferative breast tumours, group $\mathrm{N}$ that comprised 15 newly diagnosed breast cancer patients and group $\mathrm{M}$ that included 15 patients with metastatic breast cancer; their mean age was (46.27 $\pm 9.91,55.60 \pm 11.37$ and $49.60 \pm 10.55$ years) respectively.

Patients were selected from those admitted to the hospital of Medical Research Institute, Alexandria University, Alexandria, Egypt. Clinical and pathological data of the patients were prospectively collected. A written consent for participating in the study was taken according to the declaration of Helsinki and approved by the ethical committee of the Medical Research Institute. Patients with any concomitant condition that may affect the results of the study were excluded e.g., smoking, diabetes mellitus, liver dysfunction, rheumatoid arthritis or any other prolonged illness.

The newly diagnosed patients had pathologically proved stage I-III breast cancer. The metastatic disease is proved by radiological studies (CT or MRI) or pathological assessment or both. Both newly diagnosed and metastatic breast cancer patients were included in the study at the time of presentation. Blood samples were collected before starting chemotherapy.

Following 6 hours fasting period, $5 \mathrm{~mL}$ whole venous blood was withdrawn from each participating female. The blood was left to clot, centrifuged and the obtained serum was divided into 3 aliquots: $1^{\text {st }}$ aliquot was used for determination of uric acid level using an automatic autoanalyser (Olympus, Germany), the $2^{\text {nd }}$ aliquot was kept for determination of total serum oxidative capacity (TOC) and total antioxidative capacity (TAC). TOC was measured using ELISA technique (Immundiagnostik AG, Germany) and TAC was measured using (Cell Biolabs' OxiSelect ${ }^{\mathrm{TM}}$ Total Antioxidant Capacity (TAC) Kit [16].

The TAC Assay is based on the reduction of Copper(II) to Copper(I) by antioxidants such as uric acid. Upon reduction, the Copper(I) ion further reacts with a coupling chromogenic reagent that produces a color with a maximum absorbance at $490 \mathrm{~nm}$. The net absorbance values of antioxidants are compared with a known uric acid standard curve. Absorbance values are proportional to the sample's total reductive capacity. Results are expressed as " $\mu \mathrm{M}$ Copper Reducing Equivalents" or "mM Uric Acid Equivalents".

The $3^{\text {rd }}$ aliquot was used for determination of serum trace elements (copper $(\mathrm{Cu})$, zinc $(\mathrm{Zn})$ and cadmium $(\mathrm{Cd})$ ) using Atomic Absorption Spectrophotometer model (AA-6650). Serum was diluted 1:4 for determination of copper $(\mathrm{Cu})$ and cadmium $(\mathrm{Cd})$ and diluted 1:5 for determination of zinc $(\mathrm{Zn})$ using deionized water. Hollow cathode lamp specific for each element was used. Each sample was aspirated into a flame and atomized where light beam directed through the flame into a detector. Wave length absorbed in the flame is proportional to the concentration of the element in the sample over a limited concentration range. A calibration curve was set at three calibration standard levels analyzed at the beginning and the end of sample set. Blank sample analyzed for each element to demonstrate that all glassware and reagent interference are under control [17].

Clinical data of the studied groups were prospectively collected. These data included: age and menopausal status. Pathological data for the two cancerous groups (group N,M) included tumor size, nuclear grade, histological type, status and number of positive axillary lymph nodes, presence of lymphovascular invasion, status of estrogen, progesterone receptors and Her-2 (human epidermal growth factor receptor-2) expression.

\section{Statistical Analysis}

Statistical assessment was carried out with Statistical Package for Social Sciences (SPSS) version 18.0 for Windows statistical software. Quantitative variables were tested for normality using Kolmogorov-Smirnov test. Data revealed normal distribution was represented as mean \pm standard deviation, and the data revealed deviation from normal distribution was represented as median and range. Analysis of variance (ANOVA) or F-test is used for comparison between more than two means when the data are normally distributed. Kruskal-Wallis was used for testing equality of population medians among groups. Abnormally quantitative data was compared using Mann Whitney test. P value of less than 0.05 was considered statistically significant. Qualitative data was expressed using number and percent and was compared using Chi square or Monte Carlo test. Spearman's correlation test was used to investigate the relationship between non parametric quantitative variables.

\section{Results}

Statistical analysis of the results showed no significant difference between the studied groups regarding age, 
however there was a statistical significant difference in the frequency of premenopausal status $(\mathrm{P}=0.018)$ between the studied groups. Both benign breast tumours group (B) and metastatic breast cancer group (M) (46\% and 53.3\% respectively) showed higher frequency as compared to the control group (10\%) and newly diagnosed breast cancer group (20\%). Statistical analysis of the clinical data in the studied groups is summarized in (Table 1). The pathological characteristics of the breast cancer groups (newly diagnosed and metastatic) were summarized in (Table 2).

Table 1. Statistical analysis of the clinical data in the studied groups.

\begin{tabular}{cccccc}
\hline & Control $(\mathbf{n}=\mathbf{2 0})$ & $\mathbf{B}(\mathbf{n}=\mathbf{1 5})$ & $\mathbf{N}(\mathbf{n}=\mathbf{1 5})$ & $\mathbf{M}(\mathbf{n}=\mathbf{1 5})$ & $\mathbf{P}$ \\
\hline Age (years) & $47.20 \pm 10.29$ & $46.27 \pm 9.91$ & $55.60 \pm 11.37$ & $49.60 \pm 10.55$ & 0.070 \\
Menstrual state & & & & \\
Premenopausal & $2(10.0 \%)$ & $7(46.7 \%)^{*}$ & $3(20.0 \%)$ & $8(53.3 \%)^{*}$ & $0.018^{*}$ \\
Postmenopausal & $18(90.0 \%)$ & $8(53.3 \%)$ & $12(80.0 \%)$ & $7(46.7 \%)$ \\
\hline
\end{tabular}

N: Newly diagnosed breast cancer; B: Benign breast condition; M: Metastatic breast cancer; P: statistical significance with control group; ${ }^{*}$ Statistically significant at $\mathrm{P} \leq 0.05$.

Table 2. Frequency of some pathological data in the cancer groups (newly diagnosed and metastatic).

\begin{tabular}{|c|c|c|}
\hline & $N(n=15)$ & $M(n=15)$ \\
\hline \multicolumn{3}{|l|}{ Tumor size } \\
\hline T0 & $0(0.0 \%)$ & $0(0.0 \%)$ \\
\hline T1 & 2 (13.3\%) & $3(20.0 \%)$ \\
\hline $\mathbf{T} 2$ & $11(73.3 \%)$ & $10(66.7 \%)$ \\
\hline T3 & $2(13.3 \%)$ & 2 (13.3\%) \\
\hline \multicolumn{3}{|l|}{ Lymph node } \\
\hline No & $3(20.0 \%)$ & $0(0.0 \%)$ \\
\hline N1 & $5(33.3 \%)$ & 5 (33.3\%) \\
\hline N2 & $4(26.7 \%)$ & $9(60.0 \%)$ \\
\hline N3 & $3(20.0 \%)$ & $1(6.7 \%)$ \\
\hline \multicolumn{3}{|l|}{ ER, PR } \\
\hline- ve & $1(6.7 \%)$ & $3(20.0 \%)$ \\
\hline +ve & 14 (93.3\%) & 12 (80.0\%) \\
\hline \multicolumn{3}{|l|}{ HER2 } \\
\hline- ve & $9(60.0 \%)$ & $6(40.0 \%)$ \\
\hline +ve & $6(40.0 \%)$ & $9(60.0 \%)$ \\
\hline \multicolumn{3}{|l|}{ Tumor grade } \\
\hline $\mathbf{0}$ & $0(0.0 \%)$ & $0(0.0 \%)$ \\
\hline 1 & $1(6.7 \%)$ & $0(0.0 \%)$ \\
\hline 2 & $11(73.3 \%)$ & 11 (73.3\%) \\
\hline 3 & $3(20.0 \%)$ & $4(26.7 \%)$ \\
\hline
\end{tabular}

N: newly diagnosed breast cancer; M: metastatic breast cancer. 
The mean serum level of copper $(\mathrm{Cu})$ were significantly higher in the three patients groups (Benign, newly diagnosed and metastatic breast cancer) as compared to the control group $(\mathrm{P}<0.001)$. The mean serum level of Zinc (Zn) showed significant higher level in the three patient groups as compared to the control group ( $\mathrm{P}<$ 0.001), although its level was significantly lower in breast cancer groups (newly diagnosed and metastatic) than benign breast group. Serum level of Cadmium (Cd) was also significantly higher level in the three patient groups $(\mathrm{P}<0.001)$ than the control group with a significant lower level in the metastatic group than benign breast group $(\mathrm{P}<0.001)$ (Figure 1$)$.

Similarly, serum uric acid (UA) concentration and serum total anti-oxidant capacity (TAC) showed significant higher level $(\mathrm{P}=0.007)$ in both breast cancer groups $(\mathrm{N}$ and $\mathrm{M})$ as compared to the benign group $(\mathrm{B})$ while, there was no significant difference between the three patient groups(N, M and B) and the control group regarding these parameters.

However, total oxidative capacity TOC showed only significantly higher level $(P=0.05)$ in metastatic group than newly diagnosed group. TAC minus UA showed significant higher level $(P=0.007)$ only in newly diagnosed cancer group than benign breast group. Statistical analysis of the different studied laboratory parameters in the studied groups is shown in (Table 3).

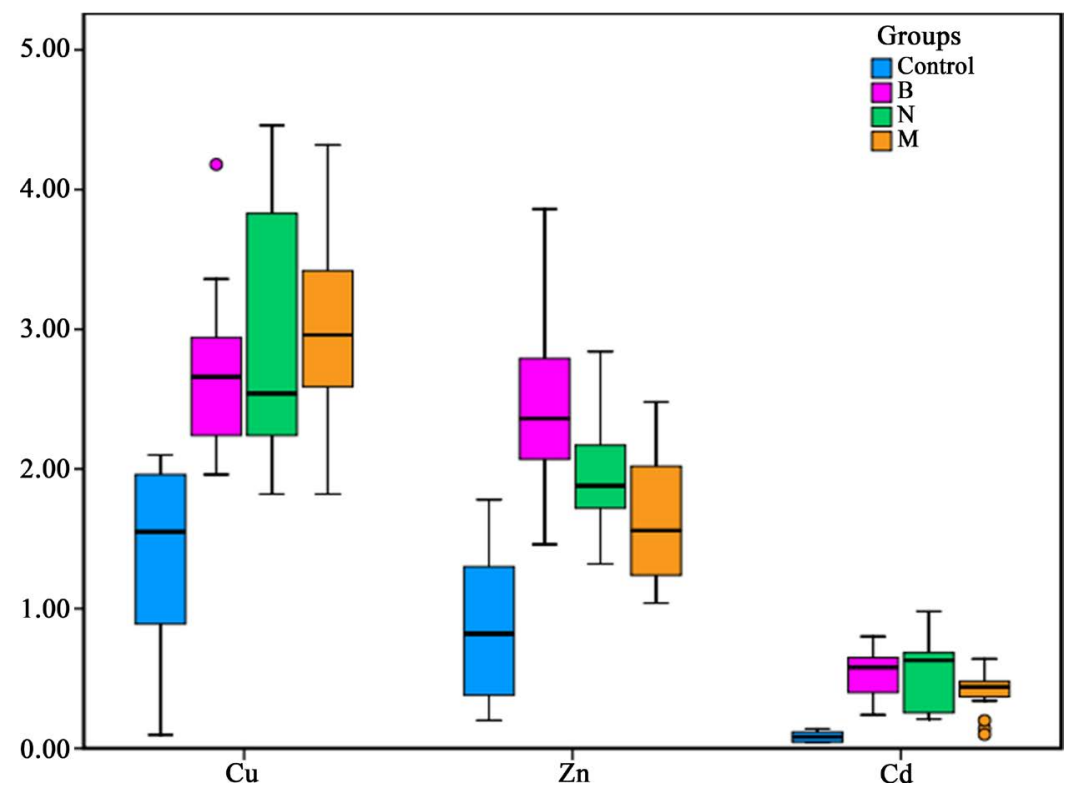

Figure 1. Comparison between the studied groups according to $\mathrm{Cu}, \mathrm{Zn}$ and $\mathrm{Cd}$.

Table 3. Statistical analysis of the different studied laboratory parameters in the studied groups.

\begin{tabular}{|c|c|c|c|c|c|}
\hline & Control (n = 20) & B (n = 15) & $N(n=15)$ & $M(n=15)$ & $\mathbf{P}$ \\
\hline $\mathrm{Cu}(\mu \mathrm{g} / \mathrm{dl})$ & $(1.34 \pm 0.74)$ & $(2.71 \pm 0.58)^{*}$ & $(2.94 \pm 0.95)^{*}$ & $(3.03 \pm 0.76)^{*}$ & $\mathrm{P} 1<0.001^{*}$ \\
\hline $\mathrm{Zn}(\mu \mathrm{g} / \mathrm{ml})$ & $(0.86 \pm 0.51)$ & $(2.47 \pm 0.64)^{*}$ & $(1.95 \pm 0.39)^{*}$ & $(1.67 \pm 0.48)^{*}$ & $\begin{array}{l}\mathrm{P} 1<0.001^{*} \\
\mathrm{P} 2<0.001^{*}\end{array}$ \\
\hline $\mathrm{Cd}(\mu \mathrm{g} / \mathrm{L})$ & $0.08(0.04-0.14)$ & $0.58(0.24-0.80)^{*}$ & $0.63(0.21-0.98)^{*}$ & $0.44(0.10-0.64)^{*}$ & $\begin{array}{l}\mathrm{P} 1<0.001^{*} \\
\mathrm{P} 2<0.001^{*}\end{array}$ \\
\hline $\mathrm{UA}(\mu \mathrm{mol} / \mathrm{L})$ & $211.1(154.6$ - 297.4) & $190.3(124.9$ - 356.9) & $226.0(136.8-410.4)^{\mathbf{}}$ & $261.7(208.2-452.0)^{\bullet}$ & $\mathrm{P} 2=0.007^{*}$ \\
\hline TOC $(\mu \mathrm{mol} / \mathrm{L})$ & $0.22(0.13-0.39)$ & $0.24(0.10-0.42)$ & $0.20(0.04-0.61)$ & $0.26(0.12-0.81)^{\circ}$ & $\mathrm{P} 3=0.05$ \\
\hline TAC $(\mu \mathrm{mol} / \mathrm{L})$ & $527.9(386.6$ - 743.5) & $475.8(312.3-892.2)$ & $565.0(342.0-1026.0)^{\bullet}$ & $654.3(520.4-1130.0)^{\bullet}$ & $\mathrm{P} 2=0.007^{*}$ \\
\hline $\begin{array}{l}\text { TAC minus } \\
\text { UA }(\mu \mathrm{mol} / \mathrm{L})\end{array}$ & $316.7(231.96$ - 446.10) & 285.49 (187.35 - 535.32) & 339.0 (205.20 - 615.59)" & 392.56 (312.25 - 678.0) & $\mathrm{P} 2=0.007^{*}$ \\
\hline
\end{tabular}

N: Newly diagnosed breast cancer; B: Benign breast condition; M: Metastatic breast. ${ }^{*} \mathrm{P} 1$ : statistical significance with control group. "P2: statistical significance with benign group. ${ }^{\circ} \mathrm{P} 3$ : statistical significance with newly diagnosed cancer group. ${ }^{*}$ Statistically significant at $\mathrm{P} \leq 0.05$. 
When the studied groups were classified according to menstrual state (Table 4), the statistical analysis in the premenopausal females showed a statistical significant difference in the serum copper level $(P=0.001)$, serum cadmium level $(P=0.010)$, serum TAC $(P=0.05)$, serum uric acid $(P=0.05)$ and TAC level minus UA level ( $P$ $=0.05)$ between the whole cancer breast group $(\mathrm{M}+\mathrm{N})$ and the control group with a significant higher level of copper in benign breast than control $(\mathrm{P}=0.001)$. In addition to a significant difference in the cadmium level between the benign group and the cancer group $(\mathrm{P}=0.01)$. On the other hand, no statistical significant difference between the studied groups regarding $\mathrm{Zn}$ and TOC levels.

While in the postmenopausal females, there were a statistical significant higher levels of copper, zinc and cadmium in the whole cancer group $(\mathrm{M}+\mathrm{N})$ and the benign group as compared to controls $(\mathrm{P}<0.001$ for all) with a significantly higher levels of zinc in the benign group than controls. There was also a significantly higher levels of TOC, uric acid and TAC-UA in the whole cancer group $(\mathrm{M}+\mathrm{N})$ as compared to controls and benign breast group $(\mathrm{P}=0.01, \mathrm{P}=0.011, \mathrm{P}=0.01$ respectively.

Upon classification of the cancer group $(\mathrm{M}+\mathrm{N})$ according to HER2 status cases, there was no statistical significance between any of the studied parameters (Table 5).

Statistical analysis of the correlation between the pathological parameters and the studied laboratory parameters in cancer groups $(\mathrm{M}+\mathrm{N})$ showed positive correlation between tumor size and serum copper $(\mathrm{r}=-0.397, \mathrm{P}$ $=0.030$ ), while on studying the correlation among the laboratory parameters in these patients groups showed positive correlation between serum copper and TOC $(r=0.461, \mathrm{P}=0.010)$ (Figure 2, Figure 3).

Table 4. Comparison of different studied lab parameters in the studied groups according to menstrual status.

\begin{tabular}{|c|c|c|c|c|}
\hline Premenopausal & Control $(n=2)$ & $N+M(n=11)$ & B $(n=7)$ & $\mathbf{P}$ \\
\hline $\mathrm{Cu}(\mu \mathrm{g} / \mathrm{dl})$ & $0.10 \pm 0.0$ & $(2.83 \pm 0.93)^{*}$ & $(2.90 \pm 0.72)^{*}$ & $\mathrm{P} 1=0.001^{*}$ \\
\hline $\mathrm{Zn}(\mu \mathrm{g} / \mathrm{ml})$ & $1.78 \pm 0.0$ & $1.87 \pm 0.43$ & $2.26 \pm 0.76$ & $P=0.327$ \\
\hline $\mathrm{Cd}(\mu \mathrm{g} / \mathrm{L})$ & $\begin{array}{c}0.04 \\
(0.04-0.04)\end{array}$ & $\begin{array}{c}0.44 \\
(0.10-0.70)^{*}\end{array}$ & $\begin{array}{c}0.58 \\
(0.36-0.80)^{*}\end{array}$ & $\begin{array}{l}\mathrm{P} 1=0.010^{*} \\
\mathrm{P} 2=0.010^{*}\end{array}$ \\
\hline TOC $(\mu \mathrm{mol} / \mathrm{L})$ & $\begin{array}{c}0.14 \\
(0.14-0.14)\end{array}$ & $\begin{array}{c}0.23 \\
(0.09-0.41)\end{array}$ & $\begin{array}{c}0.24 \\
(0.10-0.36)\end{array}$ & $\mathrm{P}=0.281$ \\
\hline $\mathrm{TAC}(\mu \mathrm{mol} / \mathrm{L})$ & $\begin{array}{c}743.5 \\
(743.5-743.5)\end{array}$ & $\begin{array}{c}654.27 \\
(342.0-728.62)^{*}\end{array}$ & $\begin{array}{c}416.35 \\
(327.12-892.2)\end{array}$ & $\mathrm{P} 1=0.05^{*}$ \\
\hline $\mathrm{UA}(\mu \mathrm{mol} / \mathrm{L})$ & $\begin{array}{c}297.4 \\
(297.4-297.4)\end{array}$ & $\begin{array}{c}261.71 \\
(136.80-291.45)^{*}\end{array}$ & $\begin{array}{c}166.54 \\
(130.85-356.88)\end{array}$ & $\mathrm{P} 1=0.05^{*}$ \\
\hline TAC Minus UA $(\mu \mathrm{mol} / \mathrm{L})$ & $\begin{array}{c}446.1 \\
(446.1-446.1)\end{array}$ & $\begin{array}{c}392.56 \\
(205.20-437.17)^{*}\end{array}$ & $\begin{array}{c}249.81 \\
(196.27-535.32)\end{array}$ & $\mathrm{P} 1=0.05^{*}$ \\
\hline Postmenopausal & $(\mathrm{n}=18)$ & $(n=19)$ & $(\mathrm{n}=8)$ & \\
\hline $\mathrm{Cu}(\mu \mathrm{g} / \mathrm{dl})$ & $1.48 \pm 0.64$ & $(3.08 \pm 0.81)^{*}$ & $(2.54 \pm 0.40)^{*}$ & $\mathrm{P} 1<0.001^{*}$ \\
\hline $\mathrm{Zn}(\mu \mathrm{g} / \mathrm{ml})$ & $0.75 \pm 0.42$ & $(1.78 \pm 0.47)^{*}$ & $(2.65 \pm 0.48)^{*}$ & $\begin{array}{l}\mathrm{P} 1<0.001^{*} \\
\mathrm{P} 2<0.001^{*}\end{array}$ \\
\hline $\mathrm{Cd}(\mu \mathrm{g} / \mathrm{L})$ & $\begin{array}{c}0.09 \\
(0.04-0.14)\end{array}$ & $\begin{array}{c}0.48 \\
(0.20-0.98)^{*}\end{array}$ & $\begin{array}{c}0.43 \\
(0.24-0.76)^{*}\end{array}$ & $\mathrm{P} 1<0.001^{*}$ \\
\hline TOC $(\mu \mathrm{mol} / \mathrm{L})$ & $\begin{array}{c}0.22 \\
(0.13-0.39)\end{array}$ & $\begin{array}{c}0.20 \\
(0.04-0.81)\end{array}$ & $\begin{array}{c}0.22 \\
(0.14-0.42)\end{array}$ & $P=0.957$ \\
\hline TAC $(\mu \mathrm{mol} / \mathrm{L})$ & $\begin{array}{c}490.70 \\
(386.60-728.62)\end{array}$ & $\begin{array}{c}624.52 \\
(446.10-1130.0)^{*}\end{array}$ & $\begin{array}{c}475.82 \\
(312.25-684.0)^{\prime}\end{array}$ & $\begin{array}{l}\mathrm{P} 1=0.010^{*} \\
\mathrm{P} 2=0.010^{-}\end{array}$ \\
\hline UA (umo/L) & $\begin{array}{c}196.28 \\
(154.64-291.45)\end{array}$ & $\begin{array}{c}249.81 \\
(178.44-452.0)^{*}\end{array}$ & $\begin{array}{c}190.33 \\
(124.90-273.60)\end{array}$ & $\begin{array}{l}\text { P1 }=0.011^{*} \\
\text { P2 }=0.011^{*}\end{array}$ \\
\hline TAC Minus UA $(\mu \mathrm{mol} / \mathrm{L})$ & $\begin{array}{c}294.42 \\
(231.96-437.17)\end{array}$ & $\begin{array}{c}374.71 \\
(267.66-678.0)^{*}\end{array}$ & $\begin{array}{c}285.49 \\
(187.35-410.40)\end{array}$ & $\begin{array}{l}\mathrm{P} 1=0.010^{*} \\
\mathrm{P} 2=0.010^{*}\end{array}$ \\
\hline
\end{tabular}

N: Newly diagnosed breast cancer; B: Benign breast condition; M: Metastatic breast. ${ }^{*} \mathrm{P} 1$ : statistical significance with control group. "P2: statistical significance with benign group. *Statistically significant at $\mathrm{P} \leq 0.05$. 
Table 5. Relation between ER, PR and HER2 with levels of trace elements for N + M groups.

\begin{tabular}{|c|c|c|c|c|}
\hline & \multirow{2}{*}{$\begin{array}{c}\text { ER } \\
-v e(n=4)\end{array}$} & \multirow{2}{*}{$\begin{array}{c}\text { PR } \\
+ \text { +ve }(n=26)\end{array}$} & \multicolumn{2}{|c|}{ HER2 } \\
\hline & & & -ve $(n=15)$ & +ve $(n=15)$ \\
\hline TOC (mmol/L) & $\begin{array}{c}0.32 \\
(0.22-0.42)\end{array}$ & $\begin{array}{c}0.21 \\
(0.04-0.61)\end{array}$ & $\begin{array}{c}0.21 \\
(0.04-0.81)\end{array}$ & $\begin{array}{c}0.24 \\
(0.09-0.61)\end{array}$ \\
\hline $\mathbf{P}$ & \multicolumn{2}{|c|}{0.127} & & \\
\hline TAC $(\mu \mathrm{mol} / \mathrm{L})$ & $\begin{array}{c}653.52 \\
(342.0-1130.0)\end{array}$ & $\begin{array}{c}639.40 \\
(446.10-1026.0)\end{array}$ & $\begin{array}{c}578.42 \\
(342.0-1130.0)\end{array}$ & $\begin{array}{c}654.27 \\
(446.10-907.05)\end{array}$ \\
\hline $\mathbf{P}$ & \multicolumn{2}{|c|}{0.668} & \multicolumn{2}{|c|}{0.851} \\
\hline UAA $(\mu \mathrm{mol} / \mathrm{L})$ & $\begin{array}{c}261.41 \\
(136.80-452.0)\end{array}$ & $\begin{array}{c}255.76 \\
(178.44-410.41)\end{array}$ & $\begin{array}{c}231.37 \\
(136.80-452.0)\end{array}$ & $\begin{array}{c}261.71 \\
(178.44-362.82)\end{array}$ \\
\hline $\mathbf{P}$ & \multicolumn{2}{|c|}{0.668} & \multicolumn{2}{|c|}{0.851} \\
\hline $\begin{array}{l}\text { TAC minus UA } \\
(\mu \mathrm{mol} / \mathrm{L})\end{array}$ & $\begin{array}{c}392.11 \\
(205.20-684.56)\end{array}$ & $\begin{array}{c}383.64 \\
(267.66-615.59)\end{array}$ & $\begin{array}{c}347.05 \\
(205.20-678.0)\end{array}$ & $\begin{array}{c}392.56 \\
(267.66-544.23)\end{array}$ \\
\hline $\mathbf{P}$ & \multicolumn{2}{|c|}{0.668} & \multicolumn{2}{|c|}{0.851} \\
\hline $\mathrm{Cu}(\mu \mathrm{g} / \mathrm{dl})$ & $3.35 \pm 1.0$ & $2.93 \pm 0.83$ & $2.79 \pm 0.86$ & $3.18 \pm 0.82$ \\
\hline $\mathbf{P}$ & \multicolumn{2}{|c|}{0.364} & \multicolumn{2}{|c|}{0.216} \\
\hline $\mathrm{Zn}(\mu \mathrm{g} / \mathrm{ml})$ & $2.06 \pm 0.40$ & $1.78 \pm 0.46$ & $1.94 \pm 0.44$ & $1.69 \pm 0.44$ \\
\hline $\mathbf{P}$ & \multicolumn{2}{|c|}{1.171} & \multicolumn{2}{|c|}{0.131} \\
\hline $\mathrm{Cd}(\mu \mathrm{g} / \mathrm{L})$ & $\begin{array}{c}0.37 \\
(0.23-0.48)\end{array}$ & $\begin{array}{c}0.48 \\
(0.10-0.98)\end{array}$ & $\begin{array}{c}0.44 \\
(0.10-0.92)\end{array}$ & $\begin{array}{c}0.48 \\
(0.14-0.98)\end{array}$ \\
\hline $\mathbf{P}$ & \multicolumn{2}{|c|}{0.314} & \multicolumn{2}{|c|}{0.442} \\
\hline
\end{tabular}

N: Newly diagnosed breast cancer; B: Benign breast condition; M: Metastatic breast; ${ }^{*}$ Statistically significant at $\mathrm{P} \leq 0.05$.

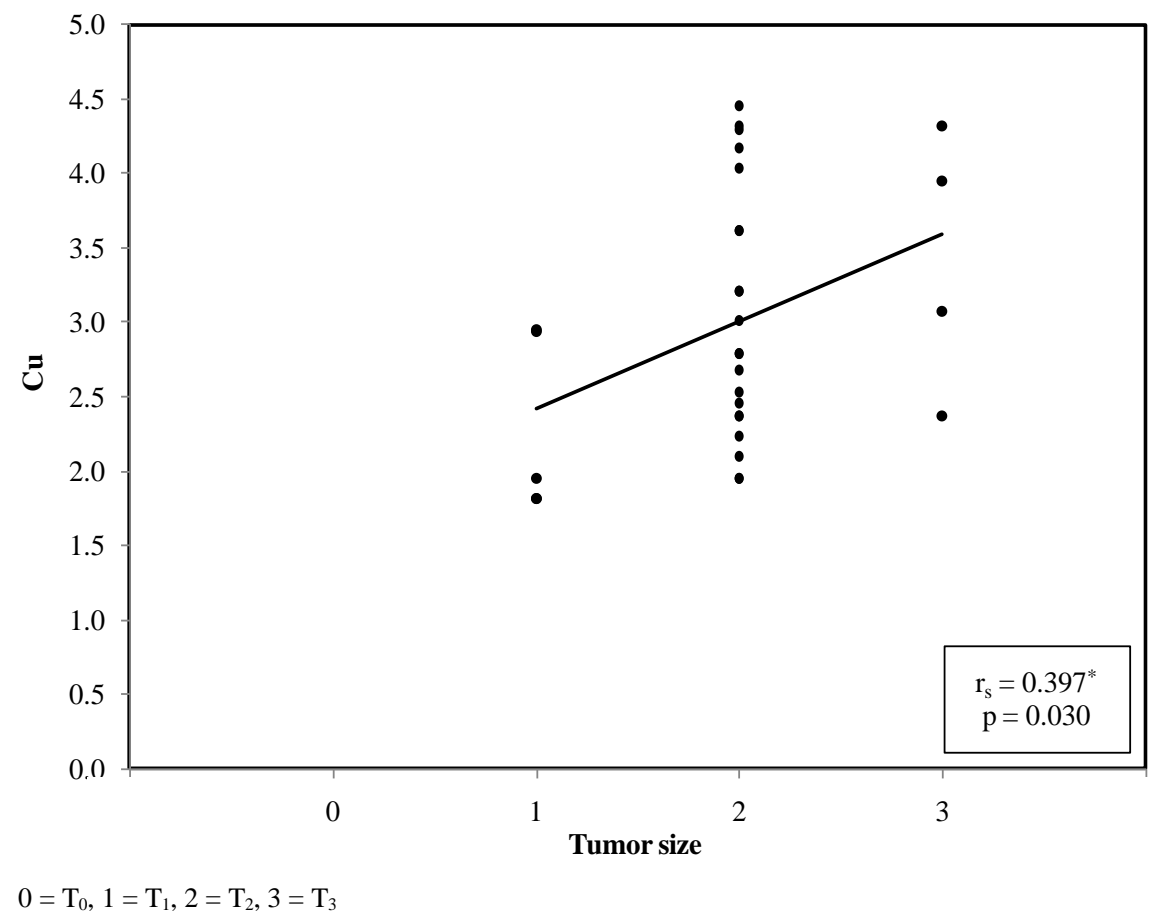

Figure 2. Correlations between tumor size with $\mathrm{Cu}$ in the whole breast cancer group $(\mathrm{N}+\mathrm{M})$. 


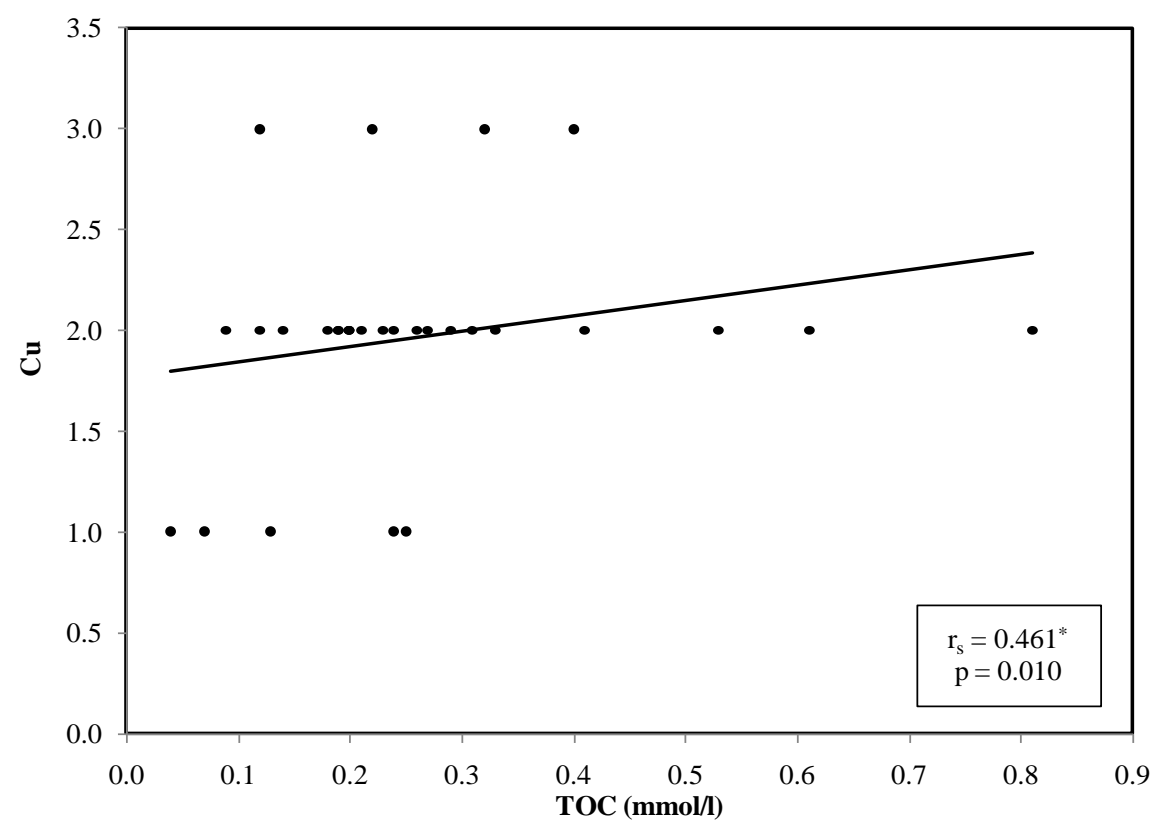

Figure 3. Correlations between TOC with $\mathrm{Cu}$ in the whole breast cancer group $(\mathrm{N}+\mathrm{M})$.

\section{Discussion}

The importance of environmental factors in the epidemiology of breast cancer is supported by the fivefold variation in national breast cancer incidence rates. However, to date, few environmental risk factors for breast cancer have been confirmed. Environmental exposure to certain trace elements has been shown to modify cancer risk [18].

It has become well established that many of these elements play essentialrole in a number of biochemical and physiological processes. It is therefore reasonable to assume that these trace elements would exert action, directly orindirectly, on the carcinogenic process such as tumor growth, invasion and metastasis, especially when in abnormal expression. A large number of epidemiological studies indicate a closeassociation between heavy metals and development of breast cancer [19].

The aim of the present study was to investigate the serum levels of some trace elements ( $\mathrm{Zn}, \mathrm{Cu}$, and $\mathrm{Cd}$ ) and the total oxidative and anti-oxidative capacity ((TOC) and (TAC)) in newly diagnosed and metastatic breast cancer patients in comparison to their serum levels in patients with benign breast tumours in order to add more knowledge to their rule in these patients groups.

The level of copper $(\mathrm{Cu})$ were significantly higher in the three patients groups (Benign, newly diagnosed and metastatic breast cancer) than the control group $(\mathrm{P}<0.001)$. Zinc $(\mathrm{Zn})$ showed significant higher level in the three patient groups as compared to the control group $(\mathrm{P}<0.001)$, although its level was significantly lower in breast cancer groups (newly diagnosed and metastatic) than benign breast group. This may due to the fact that $\mathrm{Zn}$ is required for growth as a component of the Zn finger proteins; however there is some evidence for an inverse association between $\mathrm{Zn}$ and breast cancer [13]. Cadmium (Cd) was also significantly higher level in the three patient groups $(\mathrm{P}<0.001)$ than the control group with significant lower level in the metastatic group than benign breast group $(\mathrm{P}<0.001)$.

Studies suggested that the role of $\mathrm{Cu}$ and $\mathrm{Zn}$ in tumor development could be related to their action as enzymatic co-factors involved in carcinogenesis. In addition, copper and zinc belong to the group of oxidant metals causing disruption of the oxidative balance [20].

Similar to our findings, in study carried by Mahmood AA, et al., the women with breast cancer exhibited a significant increase in the level of serum $\mathrm{Cu}$ as compared to the controls $(\mathrm{P}<0.009)$. On the other hand, serum Zn level was significantly lower in the breast cancer group $(\mathrm{P}<0.002)$ than in the control [21].

In line with these findings, Sanjeev KG et al., found that the mean serum copper levels were higher in breast cancer than in benign breast diseases and controls $(\mathrm{P}<0.001)$, patients with advanced breast cancer had higher serum copper levels than did patients with early breast cancer while, the mean serum zinc levels were lowered only in patients with advanced breast cancer as compared with controls, serum zinc levels were not decreased in 
patients with early breast cancer and benign breast diseases [22].

Opposite to our results, Abdel-Salam OM et al., found that serum copper concentrations did not differ among control and non-metastatic but were significantly lower in metastatic cancer patient group compared with the control as well as with the non-metastatic cancer group [23].

Cadmium affects cell proliferation, differentiation, apoptosis and signal transduction by enhancement of protein phosphorylation and activation of transcription and translation factors [24]. However, the Arinola OG et al., study showed that the levels of cadmium were not significantly raised in breast cancer patients compared with the controls [25].

In recent years, measurement of total antioxidant capacity of tissues and plasma has been widely used inseveral human diseases including cancer. It has been suggested that in monitoring the antioxidant defenses. The body's non-enzymatic antioxidant network can be assessed through the measurement of total antioxidant capacity (TAC). Low total antioxidant capacity could be indicative of oxidative stress or increased susceptibility to oxidative damage [26].

In our study, serum uric acid concentration and serum total anti-oxidant capacity (TAC) showed significant higher level $(\mathrm{P}=0.007)$ in both breast cancer groups $(\mathrm{N}$ and $\mathrm{M})$ as compared to the benign group $(\mathrm{B})$ while, there was no significant difference between the three patient groups (N, M and B) and the control group. However total oxidative capacity TOC showed only significantly higher level $(\mathrm{P}=0.05)$ in metastatic group than newly diagnosed group. TAC minus UA showed only significant higher level $(\mathrm{P}=0.007)$ in newly diagnosed cancer group than benign breast group.

Similarly, in the study of Bhargava AK et al., [27] serum uric acid levels increased in breast cancer patients compared to healthy control subjects and this is similar to findings reported by Krishna VG et al., study that showed that uric acid may be a protective agent due its function as antioxidant although, elevated serum uricacid is a risk factor for cancer incidence and mortality in breast cancer. According to this study, a significant rise in uric acid level in untreated women of breast cancer patients, which may be due to high oxidative stress [28].

Opposite to these findings, in the study of Abdel-Salam OM et al., there was a significant decrease in uric acid level observed in breast cancer patients on chemotherapy, values were in addition significantly lower in metastatic cancer compared with non-metastatic cancer patients. This reduction in serum uric acid might have also contributed to the lower level of TAC observed in these patients [23].

Statistical analysis of the whole cancer groups $(\mathrm{M}+\mathrm{N})$ showed positive correlation between tumor size and serum copper $(r=0.397, P=0.030)$ and positive correlation between serum copper and TOC $(r=0.461, P=$ 0.010).

When the studied groups were classified according to menstrual state, the statistical analysis in the premenopausal females showed a statistical significant difference in the serum copper level $(\mathrm{P}=0.001)$, serum cadmium level $(P=0.010)$, serum TAC $(P=0.05)$, serum uric acid $(P=0.05)$ and TAC level minus uric acid level $(P=$ $0.05)$ between the whole cancer breast group $(\mathrm{M}+\mathrm{N})$ and the control group with a significant higher level of copper in benign breast than control $(\mathrm{P}=0.001)$. In addition to a significant difference in the cadmium level between the benign group and the cancer group $(\mathrm{P}=0.01)$.

In the postmenopausal females, there were a statistical significant higher levels of copper, zinc and cadmium in the both cancer groups $(\mathrm{M}+\mathrm{N})$ and the benign group as compared to controls $(\mathrm{P}<0.001$ for all $)$ and significantly higher levels of TAC, uric acid and TAC-UA in the whole cancer groups $(\mathrm{M}+\mathrm{N})$ as compared to both control and benign breast groups $(\mathrm{P}=0.01, \mathrm{P}=0.011, \mathrm{P}=0.01$ respectively. Levels of TOC did not differ among the studied groups. Upon classification of the cancer groups $(M+N)$ according to ER, PR and HER2 status, no statistical significance were found between any of the laboratory parameters among the studied groups.

In the study conducted by Burarah A et al., the studied women were classified according to menstrual state. In contrast to our study, there was a significant decrease in the level of $\mathrm{Cd}, \mathrm{Cu}, \mathrm{Co}$, and $\mathrm{Zn}$ in pre- and postmenopausal women patients as compared to controls $(\mathrm{P}<0.001)$. $\mathrm{Cu} / \mathrm{Zn}$ ratio was declined non-significantly in patients when compared to their controls. In menstruating women, it was observed a significant decrease $(\mathrm{P}<0.05)$ in the level of $\mathrm{Cd}, \mathrm{Cu}$ and Coin patients as compared to their controls. Level of $\mathrm{Zn}$ and $\mathrm{Cu} / \mathrm{Zn}$ ratio was nonsignificantly decreased when compared to their controls [29].

\section{Conclusions \& Recommendations}

- Serum trace elements $(\mathrm{Cu}, \mathrm{Zn}, \mathrm{Cd})$ showed significant higher level in the three patients groups (Benign, 
newly diagnosed and metastatic breast cancer) compared to control group.

- Zn level was significantly lower in breast cancer groups (newly diagnosed and metastatic) than benign breast group.

- The observed increase in levels of trace elements in breast cancer groups may suggest the role for these trace elements in the initiation, promotion and progression of breast cancer.

- The findings in the present study suggested elevated not only total serum antioxidant capacity, (TAC) and uric acid but also oxidative stress (TOC) in patients with cancer breast. However, total oxidative capacity TOC showed only significantly higher level in metastatic group than newly diagnosed group.

- It seems that the increased levels of trace elements could lead to formation of free radicals or other reactive oxygen species inducing oxidative stress.

- It is recommended to use trace elements and antioxidant activity as biomarkers for breast cancer. The serum profile of these trace metals may be helpful in predicting prognosis of breast cancer.

- Our findings in this study warrant further investigations on larger sample size, more other trace elements and multipleserum samples with different time intervals.

\section{Acknowledgements}

All authors have contributed significantly to this work.

\section{Conflicts of Interest}

The authors declare that there's no conflict of interest that could be perceived as prejudicing the impartiality of the study.

\section{References}

[1] Parkin, D.M. and Fernández, L.M. (2006) Use of Statistics to Assess the Global Burden of Breast Cancer. Breast Journal, 1, 70-80. http://dx.doi.org/10.1111/j.1075-122X.2006.00205.X

[2] Amal, S.I., Hussein, M.K., Nabiel, N.M., Hoda, B. and Hossam, K. (2014) Cancer Incidence in Egypt: Results of the National Population-Based Cancer Registry Program. Journal of Cancer Epidemiology, 18, Article ID: 437971.

[3] Dumitrescu, R.G. and Cotarla, I. (2005) Understanding Breast Cancer Risk. Where Do We Stand in 2005? Journal of Cellular and Molecular Medicine, 9, 208-221. http://dx.doi.org/10.1111/j.1582-4934.2005.tb00350.x

[4] Halliwell, B. and Gutteridge, J.M. (2006) Free Radicals in Biology and Medicine. 4th Edition, Clarendon Press, Oxford.

[5] Halliwell, B. (2007) Oxidative Stress and Cancer: Have We Moved Forward? Biochemical Journal, 401, 1-11. http://dx.doi.org/10.1042/BJ20061131

[6] Badid, N., Ahmed, F.Z., Merzouk, H., Belbraouet, S., Mokhtari, N. and Merzouk, S.A. (2010) Oxidant/Antioxidant Status, Lipids and Hormonal Profile in Overweight Women with Breast Cancer. Pathology and Oncology Research, 16, 159-167. http://dx.doi.org/10.1007/s12253-009-9199-0

[7] Kasapovic, J., Pejic, S., Todorovic, A., Stojiljkovic, V. and Pajovic, S.B. (2008) Antioxidant Status and Lipid Peroxidation in the Blood of Breast Cancer Patients of Different Ages. Cell Biochemistry \& Function, 26, 723-730. http://dx.doi.org/10.1002/cbf.1499

[8] Jevtic, M., Velicki, R., Popovic, M., Cemerlic-Adjic, N., Babovic, S.S. and Velicki, L. (2010) Dietary Influence on Breast Cancer. Journal of BUON, 15, 455-461.

[9] Yeon, J.Y., Suh, Y.J., Kim, S.W., Baik, H.W., Sung, C.J., Kim, H.S. and Sung, M.K. (2011) Evaluation of Dietary Factors in Relation to the Biomarkers of Oxidative Stress and Inflammation in Breast Cancer Risk. Nutrition, 27, 912918. http://dx.doi.org/10.1016/j.nut.2010.10.012

[10] Muraoka, S. and Miura, T. (2003) Inhibition by Uric Acid of Free Radicals That Damage Biological Molecules. Basic \& Clinical Pharmacology \& Toxicology, 93, 284-289. http://dx.doi.org/10.1111/j.1600-0773.2003.pto930606.x

[11] Aghvami, T., Djalali, M. and Kesharvarz, A. (2006) Plasma Level of Antioxidant Vitamins and Lipid Peroxidation in Breast Cancer Patients. Iranian Journal of Public Health, 35, 42-47.

[12] Bertini, I. and Cavallaro, G. (2008) Metals in the "Omics” World: Copper Homeostasis and Cytochrome c Oxidase Assembly in a New Light. JBIC Journal of Biological Inorganic Chemistry, 13, 3-14. http://dx.doi.org/10.1007/s00775-007-0316-9

[13] Navoro, S.S. and Rohan, T.E. (2007) Trace Elements and Cancer Risk: A Review of the Epidemiologic Evidence. 
Cancer Causes Control, 18, 7-27. http://dx.doi.org/10.1007/s10552-006-0057-z

[14] Leonard, S.S., Bower, J.J. and Shi, X. (2004) Metal-Induced Toxicity, Carcinogenesis, Mechanisms and Cellular Responses. Molecular and Cellular Biochemistry, 255, 3-10. http://dx.doi.org/10.1023/B:MCBI.0000007255.72746.a6

[15] Silva, A. and Poletti, M.E. (2009) Determination of Ca, Fe, Cu and Zn and Their Correlations in Breast Cancer and Normal Adjacent Tissues. X-Ray Spectrometry, 38, 103-111. http://dx.doi.org/10.1002/xrs.1126

[16] Trachootham, D., Lu, W., Ogasawara, M.A., Nilsa, R.D. and Huang, P. (2008) Redox Regulation of Cell Survival. Antioxidants \& Redox Signaling, 10, 1343-1374. http://dx.doi.org/10.1089/ars.2007.1957

[17] Dastgheib, L., Mostafavi-Pour, Z., Abdorazagh, A.A., Khoshdel, Z., Sadat Sadati, M. and Ahrari, I. (2014) Comparison of $\mathrm{Zn}, \mathrm{Cu}$, and Fe Content in Hair and Serum in Alopecia Areata Patients with Normal Group. Dermatology Research and Practice, 2014, Article ID: 784863. http://dx.doi.org/10.1155/2014/784863

[18] Gallagher, C.M., Chen, J.J. and Kovach, J.S. (2010) Environmental Cadmium and Breast Cancer Risk. Aging, 2, 804814.

[19] Alatise, O.I. and Schrauzer, G.N. (2010) Lead Exposure: A Contributing Cause of the Current Breast Cancer Epidemic in Nigerian Women. Biological Trace Element Research, 136, 127-139. http://dx.doi.org/10.1007/s12011-010-8608-2

[20] Shams, N., Said, S.B., Salem, T.A., Abdel-Rahman, R.H., Roshdy, S. and Abdel Rahman, R.H. (2012) Metal-Induced Oxidative Stress in Egyptian Women with Breast Cancer. The Egyptian Journal of Forensic Sciences and Applied Toxicology, 12, 187-199. http://dx.doi.org/10.12816/0005067

[21] Mahmood, A.A., Bilal, K.M. and Ibrahim, R.T. (2012) Influence of Some Trace Elements and Biochemical Parameters on Breast Cancer. Journal of Education Science, 25, 34-43.

[22] Sanjeev, K.G., Vijay, K.S., Vaidya, M.P. and Roy, S.K. (2006) Serum Trace Elements and Cu/Zn Ratio in Breast Cancer Patients. Journal of Surgical Oncology, 46, 178-181.

[23] Abdel-Salam, O.M., Youness, E.R. and Hafez, H.F. (2011) The Antioxidant Status of the Plasma in Patients with Breast Cancer Undergoing Chemotherapy. Open Journal of Molecular and Integrative Physiology, 1, 29-35. http://dx.doi.org/10.4236/ojmip.2011.13005

[24] Siewit, C.L., Gengler, B., Vegas, E., Puckett, R. and Louie, M.C. (2010) Cadmium Promotes Breast Cancer Cell Proliferation by Potentiating the Interaction between ER Alpha and c-Jun. Molecular Endocrinology, 24, 981-992. http://dx.doi.org/10.1210/me.2009-0410

[25] Arinola, O.G. and Charles-Davies, M.A. (2008) Micronutrient Levels in the Plasma of Nigerian Females with Breast Cancer. African Journal of Biotechnology, 7, 1620-1623.

[26] Koracevic, D., Koracevic, G., Djordjevic, V., Andrejevic, S. and Cosic, V. (2001) Method for the Measurement of Antioxidant Activity in Human Fluids. Journal of Clinical Pathology, 54, 356-361. http://dx.doi.org/10.1136/jcp.54.5.356

[27] Bhargava, A.K., Mathur, M., Diwan, R. and Bohra, V.D. (2015) Analysis of Serum Uric Acid and Bilirubin in Breast Cancer. International Journal of Scientific Research, 4, 2277-8179.

[28] Krishna, V.G., Bhaskar, R.D., Muni, K.D., Usha, B., Murli, K.V. and Raghava, R.T. (2011) Clinical Evaluation of Oxidative Stress in Women with Breast Cancer. Recent Research in Science and Technology, 3, 55-58.

[29] Burarah, A., Sameen, A., Mahjabeen, S., Rukhshan, K. and Muddasar, Z. (2012) Serum Trace Elements in Diagnosis of Breast Malignancy. Journal of Ayub Medical College, 24, 62-66. 